\title{
ОСНОВНІ ЗАВДАННЯ ВИЩОЇ МЕДИЧНОЇ ОСВІТИ У ПРОЦЕСІ РЕФОРМУВАННЯ СИСТЕМИ ОХОРОНИ ЗДОРОВ'Я УКРАЇНИ
}

\section{MAIN TASKS OF HIGHER MEDICAL EDUCATION IN THE PROCESS OF REFORMATION OF PUBLIC HEALTH SYSTEM OF UKRAINE}

\author{
Ministry of Public Health of Ukraine
}

\begin{abstract}
У статті викладено основні завдання вищої медичної освіти у процесі реформування системи охорони здоров'я України для забезпечення викликів сьогодення щодо підготовки лікаря нової якості.
\end{abstract}

The article adduces the main tasks of higher medical education in the process of reformation of Public Health System of Ukraine for supply of challenges of the present time regarding the training of a doctor of new quality.

Вступ. Питання розвитку вітчизняної системи охорони здоров'я є одними із ключових завдань державної політики на сучасному етапі. Упродовж останніх років керівництвом держави здійснюються системні кроки щодо реформування системи медичного обслуговування населення. Головною метою реформ $\epsilon$ поліпшення здоров'я населення, забезпечення рівного й справедливого доступу всіх громадян до медичних послуг належного рівня якості.

Саме здоров'я є інтегральним показником суспільного розвитку країни, відображенням іiї соціальноекономічного рівня, провідним чинником формування демографічного, економічного, трудового та культурного потенціалу.

Сьогодні ми спільно визначаємо стан здоров'я населення як загальнонаціональний пріоритет. Суспільство та нація в цілому повинні усвідомлювати, що їх могутність - це здорові, заможні люди, здорове покоління нащадків, які прийдуть на зміну нам.

Нині у владі та суспільстві сформувалося нове критичне розуміння соціальних детермінант здоров'я для перегляду існуючих механізмів стратегічного управління в інтересах здоров'я нації, політики охорони здоров'я та надання медичної допомоги населенню.

Це і $є$ головним рушієм проведення реформи медичного обслуговування, основні принципи якої визначені Президентом України, шановним Віктором Федоровичем Януковичем. Вона спрямована на створення ефективної системи охорони здоров'я в країні, підвищення якості надання та доступності медичної допомоги. Серед ключових пріоритетів галузі є ста(C) Р. В. Богатирьова білізація демографічної ситуації та боротьбаз неінфекційними захворюваннями і факторами їх ризику.

Поняття “здоров'я” має мультифакторіальний характер. Навіть можливості медицини мають свої межі, коли людина не береже свого здоров'я і не слідкує за ним.

За даними Всесвітньої організації охорони здоров'я, упродовж наступних 5 років уперше в історії людства кількість людей віком старше 65 років буде більшою від кількості дітей віком до 5 років. За прогнозами науковців, кількість людей похилого віку у 2050 році перевищуватиме кількість осіб віком до 14 років. Ця проблема значно ширша, вона лежить у площині поліпшення соціально-побутових умов наших громадян, їх способу життя, моралі, відмові від шкідливих звичок, відродженні духовних традицій нашого народу, реальному впливі на тенденції у молодіжному середовищі. Якщо Україна - європейська держава, то і стандарти життя, побуту, довкілля та культури мають відповідати євроінтеграційному спрямуванню.

Ці тези підтверджують слова корифея вітчизняної медицини Миколи Івановича Пирогова: “Майбутнє належить медицині профілактичній”, покладають надзвичайно важливе завдання на вищі медичні навчальні заклади щодо розробки актуалізованих навчальних програм відповідно до викликів сьогодення.

Основна частина. Серед невідкладних завдань вітчизняної системи охорони здоров'я $€$ підготовка висококваліфікованих спеціалістів відповідно до сучасних стандартів надання медичної допомоги на- 
селенню з урахуванням сучасного рівня розвитку медичної науки і практики.

Медичні університети не стоять осторонь цієї програми, проте вони повинні брати більш активну участь у процесах реформування охорони здоров'я, науково обгрунтовуючи ці шляхи та забезпечуючи практичну підготовку відповідних кадрів. Окрім того, потужна система вищих медичних навчальних закладів має відігравати провідну роль у наданні спеціалізованої медичної допомоги населенню.

Вимоги сьогодення потребують підготовки спеціалістів на якісно новому рівні. Пройшовши підготовку на додипломному і післядипломному етапах, кожен випускник повинен бути готовим до роботи для надання первинного або вторинного рівня медичної допомоги. Адже на сьогодні особливо гостро стоїть питання забезпеченості кадровими ресурсами закладів охорони здоров' я саме первинного рівня надання медичної допомоги. Забезпечення галузі лікарями загальної практики - сімейними лікарями, особливо закладів охорони здоров’ я сільської місцевості, $є$ і буде пріоритетним напрямом роботи Міністерства охорони здоров’я найближчим часом.

Саме тому підготовка лікарів загальної практики сімейних лікарів потребує оновлення програмних та навчально-методичних ресурсів з метою адаптації спеціалістів для роботи у первинній ланці, у сільській місцевості, забезпечуючи відповідний рівень знань та практичних навичок і умінь не тільки 3 надання невідкладної допомоги, внутрішньої медицини, хірургії, акушерства та гінекології, але й $з$ питань профілактичної медицини, зокрема санітарно-освітньої та протиепідемічної роботи. Вищі навчальні заклади мають створити навчально-практичні тренінгові центри на базі закладів охорони здоров'я первинного рівня надання медичної допомоги, в яких студенти, окрім теоретичної підготовки, самостійно та під контролем викладача чи лікаря загальної практики сімейного лікаря повинні брати участь у наданні медичної допомоги, вивчати медичну документацію, займатись питаннями диспансеризації та санітарноосвітньої роботи 3 населенням. 3 цією метою навчальні бази студентів потрібно укомплектувати сучасним діагностичним та лікувальним обладнанням.

Швидкий розвиток науково-технічного прогресу вимагає від університетів досягнення якісного нового рівня способу подання навчального матеріалу шляхом впровадження новітніх інформаційних технологій. Серед них: телекомунікаційні лекції та відеоконференції; окремі Web-портали навчально-методичних матеріалів; комп'ютеризована бібліотечна система; віртуальні комп’ютерні програми для вивчення як теоретичних, так і клінічних дисциплін; дистанційні методи навчання та оцінювання знань і практичної компетентності студентів тощо.

Слід виділити телемедичні технології, якими має опанувати медичний працівник і які невдовзі стануть повсякденням лікувально-профілактичної діяльності, зокрема: електронна реєстратура, система дистанційного запису пацієнтів на консультацію до лікаря, система дистанційної ЕКГ-діагностики на основі GSM-зв' язку, система лабораторної діагностики та передачі зображень тощо.

Безумовно, за сучасними інформаційними технологіями розповсюдження знань, віртуальними університетами майбутнє. Саме це шлях до створення суспільства знань, до якого йде людство. Остання зустріч лідерів світової політики та економіки у Давосі, в якій брав участь і Президент України Віктор Федорович Янукович, була присвячена поширенню тенденцій використання інтернет-освіти та телекомунікаційних технологій для забезпечення глобального доступу до якісної освіти. Це революційні зміни, які повинні втілюватись і у процесі навчання медиків. У кожному вищому навчальному закладі потрібно створювати "хмарні" інтерактивні освітні портали з використанням новітніх інтернет-технологій. У нас є позитивний досвід роботи відповідного центру в Національній медичній академії післядипломної освіти. Активно використовується інтернет-освіта у вищих медичних навчальних закладах м. Тернополя та м. Запоріжжя, яку треба активно розвивати і поширювати на всю вищу медичну освіту.

Впровадження телекомунікаційних технологій до навчального процесу має відповідати тенденції постійного розширення сфери їх застосування у практичній діяльності лікаря. Все більшого значення набувають передача даних діагностичних досліджень, проведення інтерактивних консультацій хворих із залученням фахівців різних профілів, регіонів. Особливо ця проблема актуальна для консультації хворих у віддалених районах і сільській місцевості.

У зв'язку зі швидким розвитком науки, інформаційних технологій, щоденною появою нових фактів про останні досягнення у різних сферах медицини необхідно переглянути існуючу на сьогодні періодичність коригування робочих навчальних планів та програм. Це дасть змогу студенту отримувати найсучасніші знання з урахуванням наукових досягнень, практичних винаходів, сучасних протоколів та стандартів лікування на засадах доказової медицини.

Техногенність діагностичного та лікувального процесу набуває все більшого значення. Лікарні осна- 
щують сучасним обладнанням, яке потребує фахового підходу при його експлуатації. Отже, натепер назріла необхідність розробки відповідних навчальних планів та програм підготовки студентів вищих навчальних закладів сфери управління МОН з медико-інженерних спеціальностей для роботи у закладах охорони здоров'я та медичних науково-дослідних установах.

Вищим навчальним закладам необхідно організувати систематичну роботу щодо прогнозування змісту освіти для професійної підготовки фахівців на перспективу з урахуванням компетентнісного підходу та викликів часу, відповідно, забезпечувати модернізацію навчального процесу на засадах новітніх досягнень у сфері освіти та науки, охорони здоров'я, враховувати це при розробці навчальних планів та програм.

Міністерство вимагає від вищих медичних навчальних закладів змінити форму підготовки організаторів та управлінців в охороні здоров' я. Обов' язки, які покладаються на керівника системи охорони здоров'я, в умовах реформування системи покладають на нього обов'язок володіння управлінськими навиками відповідно до основних елементів управлінського циклу: аналіз ситуації, прийняття рішення, організація його виконання і контроль. У системі післядипломної освіти повною мірою необхідно запровадити підготовку менеджерів з охорони здоров'я. У деяких навчальних закладах така підготовка вже здійснюється, проте вона повинна бути впроваджена у кожному університеті на факультетах післядипломної освіти.

3 урахуванням положень новоприйнятого Закону України "Про екстрену медичну допомогу" вищі медичні навчальні заклади мають привести обсяги підготовки та підвищення кваліфікації лікарів і молодших спеціалістів у відповідність до потреб закладів системи екстреної медичної допомоги, забезпечити оновлення програм післядипломної підготовки лікарів за спеціальністю “Медицина невідкладних станів” та фельдшерів за спеціальністю “Лікувальна справа. Невідкладні стани”, створити відповідні кафедри.

Міністерство постійно працює над питанням поліпшення якості правової підготовки медичних працівників. Обізнаність медичних працівників зі своїми правами та обов'язками, знання прав та обов'язків пацієнтів та їх родичів є запорукою належного рівня якості надання медичної допомоги населенню України. У 2020 році первинну медичну допомогу населенню будуть надавати понад 30 тисяч сімейних лікарів, більшість 3 яких будуть працювати як самостійні суб'єкти господарювання. Ми впритул підійшли до формування ринку медичних послуг.
Саме тому набуття лікарями правової інформації щодо власного правового статусу, організаційно-правових форм діяльності з надання медичних послуг, управління якістю медичних послуг, правових умов ліцензування, оподаткування, ціноутворення та фармацевтичного забезпечення медичної діяльності підвищить рівень господарської самостійності практикуючих лікарів, буде сприяти повному усвідомленню ними юридичної відповідальності за власні дії.

Міністерством нині зроблено чимало - всі студенти-медики обов'язково вивчають дисципліну “Медичне правознавство”, розроблені, затверджені, впроваджені типові навчальні програми із цієї дисципліни. Окрім того, фахівці МО3 України та вищих медичних навчальних закладів брали участь у розробці типової навчальної програми “Медичне право України” для майбутніх правознавців, яка затверджена та впроваджена у діяльність вищих юридичних навчальних закладів Міністерством освіти і науки України. Міністерство завжди буде підтримувати всі ініціативи вищих навчальних закладів щодо створення окремих кафедр медичного права у вищих медичних навчальних закладах.

Проведення реформ медичної галузі вимагає належного наукового супроводу, до чого необхідно залучити всі профільні кафедри соціальної медицини та організації охорони здоров’я вищих медичних навчальних закладів.

Наукова робота вищих медичних навчальних закладів також має бути поєднана 3 процесами реформування медичної галузі. Наслідком отриманих результатів наукових досліджень, впровадження у клінічну практику сучасних принципів діагностики, лікування та профілактики повинна бути оптимізація діяльності профільних відділень лікувально-профілактичних закладів, зміна їхньої структури та переосмислення завдань.

Проведення оптимізації закладів вторинного рівня медичної допомоги, відділень стаціонарів повинно бути також науково обгрунтованим з урахуванням стану здоров'я населення регіону, показників захворюваності, поширеності хвороб тощо. У зв'язку з цим на регіональному рівні кожна область має розробити свій адекватний план реформування системи охорони здоров’я, до створення якого повинні бути залучені науковці регіональних вищих медичних навчальних закладів. Це дасть можливість значною мірою уникнути помилок, необгрунтованих дій і заходів.

Активна участь вищих навчальних закладів та науково-дослідних установ у пошуку наукових грантів, зокрема за кордоном, запровадження у методологію 
наукового пошуку засад доказової медицини, публікації у відомих міжнародних часописах є запорукою ефективності наукових досліджень та раціонального використання бюджетних коштів.

Одним із пріоритетів реформування медичної допомоги на третинному рівні $є$ створення університетських клінік та лікарень. Це дозволить поліпшити якість медичної допомоги та ефективність використання потенціалу обласних лікарень, а також вищих медичних навчальних закладів IV рівня акредитації та закладів післядипломної освіти. Світова практика свідчить, що такі лікувально-профілактичні заклади мають суттєві переваги перед звичайними лікарнями за рахунок кращої матеріально-технічної бази та високопрофесійного кадрового складу, що дозволяє надавати ефективну медичну допомогу населенню за усіма медичними спеціальностями. Звісно, підготовка майбутніх спеціалістів у таких лікарнях більше відповідає сучасним вимогам.

Висновок. Роль вищих медичних навчальних зак- ладів України у процесі реформування медичної галузі полягає в забезпеченні викликів сьогодення щодо підготовки лікаря нової якості, який повинен бути насамперед готовим до роботи у первинній ланці системи охорони здоров'я та в умовах запровадження страхової медицини. Медичні університети мають відігравати провідну роль у подальшому ході реформування організації вторинного і третинного рівнів надання медичної допомоги шляхом розробки й упровадження високотехнологічних методів діагностики і лікування й забезпечення післядипломного навчання лікарів відповідних спеціальностей.

Завдання, які стоять перед вищою медичною школою у ході реформування сфери охорони здоров'я, будуть вирішені за умови подальшого формування єдиного медичного простору, забезпечення інтегруючої ролі вищих медичних навчальних закладів як потужних регіональних центрів надання спеціалізованої та високоспеціалізованої медичної допомоги населенню у системі охорони здоров'я.

\section{Лiтература}

1. Про Національний план дій на 2012 рік щодо впровадження Програми економічних реформ на 2010-2014 роки “Заможне суспільство, конкурентоспроможна економіка, ефективна держава": Указ Президента України № 187/2012.

2. Богатирьова Р. В. Детермінанти здоров'я та національна безпека / Р. В. Богатирьова. - Київ : ВД “Авіценна”, 2011. $-448 \mathrm{c}$.

3. Медичне законодавство: правова регламентація

лікарської діяльності / [М. В. Банчук, В. Ф. Москаленко, Б. В. Михайличенко та ін.]. - Київ : ВСВ “Медицина”, 2011. $-494 \mathrm{c}$.

4. Стратегія державної кадрової політики на 2012-2020 роки [Електронний ресурс]: Указ Президента України від 1 лютого 2012 року № 45/2012. - Режим доступу: http:// president.gov.ua/doc/14429 